\title{
A comparative analysis of resistance models for austenitic stainless-steel girders subjected to concentrated loads
}

\section{Análisis comparativo de modelos de resistencia para vigas esbeltas de acero inoxidable austenítico sometidas a cargas concentradas}

\author{
Carlos Graciano ${ }^{1}$, Nelson Loaiza ${ }^{2,3}$, Euro Casanova ${ }^{4}$ \\ ${ }^{1}$ Departamento de Ingeniería Civil, Universidad Nacional de Colombia, Medellín, Colombia. \\ Email: cagracianog@unal.edu.co. Orcid: 0000-0003-0659-7963. \\ ${ }^{2}$ Facultad de Ingeniería, Departamento de Ingeniería Civil, Universidad de Medellín, Colombia. \\ Email: naloaizar@unal.edu.co. Orcid: 0000-0003-2494-5650. \\ ${ }^{3}$ Politécnico Colombiano Jaime Isaza Cadavid PCJIC, Colombia. \\ ${ }^{3}$ Departamento Ingeniería Civil y Ambiental, Universidad del Bío-Bío, Chile. \\ Email: ecasanova@ubiobio.cl. Orcid: 0000-0002-1701-0550.
}

Received: 10 August 2021. Accepted: 16 October 2021. Final version: 21 November 2021.

\begin{abstract}
The increasing use of stainless steel in construction has led to the need of developing resistance models for structural elements made of this material. Unlike carbon steels, stainless steel alloys exhibit stress-strain curves with a pronounced strain hardening capacity and reasonable ductility that should be considered in the design. This difference in behavior makes the formulations used for carbon steel conservative when designing with stainless steel. Therefore, this paper presents a comparative analysis of resistance models for slender austenitic stainless-steel beams subject to concentrated loads. First, the failure mechanisms of stainless-steel beams are presented using a nonlinear finite element model. From this validated numerical model, a database obtained from a parametric analysis that covers a wide range of geometries is presented. Subsequently, this database is used to perform a comparison between various resistance models available in the literature. These models correspond to both international design codes and models obtained through machine learning. Finally, the numerical results show considerable improvement in the predicted ultimate resistances for slender stainless steel plate girders subjected to patch loading.
\end{abstract}

Keywords: ultimate resistance; finite element; nonlinear analysis; stainless steel; patch loading.

\section{Resumen}

El creciente uso de acero inoxidable en la construcción ha creado la necesidad de desarrollar modelos de resistencia para elementos estructurales fabricados con este material. A diferencia de los aceros de carbono, las aleaciones de acero inoxidable exhiben curvas esfuerzo-deformación con una pronunciada capacidad de endurecimiento por

ISSN Printed: 1657 - 4583, ISSN Online: 2145 - 8456, CC BY-ND 4.0 (c) (1)

How to cite: C. Graciano, N. Loaiza, E. Casanova, "A comparative analysis of resistance models for austenitic stainless-steel girders subjected to concentrated loads," Rev. UIS Ing., vol. 21, no. 1, pp. 95-102, 2022, doi: https://doi.org/10.18273/revuin.v21n1-2022008. 
deformación y ductilidad razonable que deben ser consideradas en el diseño. Esta diferencia en el comportamiento hace que las formulaciones utilizadas para acero al carbono sean conservadoras al momento de diseñar con acero inoxidable. Por lo tanto, este trabajo presenta un análisis comparativo de modelos de resistencia para vigas esbeltas de acero inoxidable sometidas a cargas concentradas. En primer lugar, se presentan los mecanismos de falla de vigas de acero inoxidable utilizando un modelo no lineal por elementos finitos. A partir de este modelo numérico validado se presenta una base de datos obtenida a partir de un análisis paramétrico que cubre un amplio rango de geometrías. Posteriormente, esta base de datos se utiliza para realizar una comparación entre varios modelos de resistencia disponibles en la literatura. Estos modelos corresponden tanto a códigos de diseño internacionales como a modelos obtenidos a través de aprendizaje de máquina (machine learning). Finalmente, los resultados muestran una mejora considerable en la predicción de la resistencia última de las vigas esbeltas de acero inoxidable sometidas a cargas concentradas.

Palabras clave: resistencia última; elementos finitos; análisis no lineal; acero inoxidable; carga concentrada.

\section{Introduction}

At present, the current generation of international design specifications for metal structures (stainless steel and aluminum) [1], [2], [3] have been developed based on carbon steel guidelines [4], [5]. Stainless steel and aluminum exhibit nonlinear material strain-stress curves with significant strain hardening and reasonable ductility. Several research projects [6], [7], [8], [9], [10], [11], [12], indicate that for these metal alloys their strain hardening capabilities should be considered for strength calculations to achieve economical and efficient structural designs. Figure 1 depicts the notation used herein for stainless-steel plate girders subjected to patch loading.
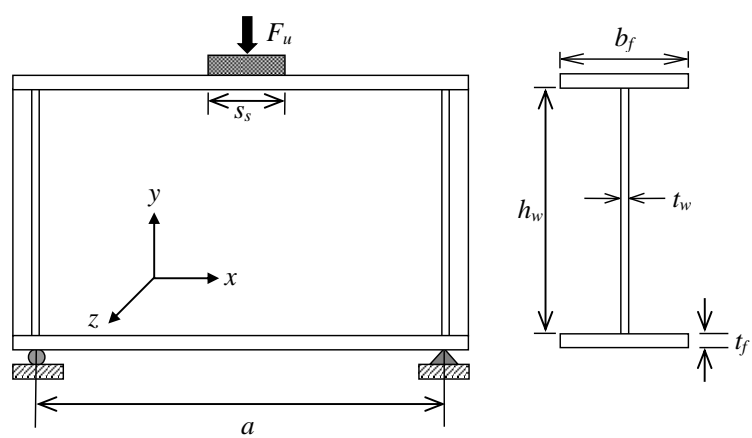

Figure 1. Notation of a stainless-steel plate girder subjected to patch loading.

In the American [1] and European standards [2] for the design of stainless-steel members, the formulation to calculate the resistance of stainless-steel plate girders subjected to patch loading are derived from those corresponding to carbon steel plate girders [4], [5]. The formulation found in the EC3 Part 1-5 [5] is based upon a plastic collapse mechanism developed for carbon steel girders [13]. In consequence, the difference in the stressstrain behavior between stainless steel and carbon steel is neglected.
The resistance of stainless-steel girders subjected to patch loading has been investigated experimentally and numerically [14], [15]. After comparing the experimental and numerical results with theoretical predictions obtained with international standards for carbon steel [4], [5], the results showed that the predicted resistances were generally conservative, especially for stocky girders, i.e girders with low web slenderness ratios.

Recently, Graciano et al. [16] and dos Santos and Gardner [17] calibrated the resistance model for patch loading employed for carbon steel in the EC3 Part 1-5 [5] to predict the corresponding resistance of austenitic stainless steel plate girders. The results showed a significant improvement in the theoretical predictions obtained with the calibrated models.

Finite element analysis (FEA) has been proven to be a reliable tool to predict the behavior of stainless-steel girders subjected to patch loading [14], [15], [16], [17], [18]. To standardize and facilitate FEA, the European Committee for Standardization [19], [20] developed a designation system that abbreviates the features included in various structural analyses. For elastic analysis, the designation system includes (1) linear elastic analysis (LA), (2) geometrically nonlinear analysis (GNA), and (3) geometrically nonlinear analysis with imperfections (GNIA). For plastic analysis, the system includes (1) first-order materially nonlinear analysis (MNA), (2) geometrically and materially nonlinear analysis (GMNA), and the more advanced (3) geometrically and materially nonlinear analysis with imperfections (GMNIA). GMNIA is mostly recommended to account for the influence of material nonlinearity and initial geometric imperfections.

As mentioned above, stainless steel alloys exhibit a stress-strain behavior with larger strain-hardening than carbon steel alloys, which should be taken into consideration in the design. 
Therefore, this paper aims at conducting a comparative analysis of resistance models for the design of austenitic stainless-steel girders subjected to patch loading.

The data used for comparison is made of a collection of numerical simulations obtained through GMNIA. These data cover a wide range of geometries. Numerically computed resistances are compared to values predicted using available formulae from the literature. Finally, the numerical results show that there is a considerable improvement in the predicted patch loading resistances of stainless-steel plate girders.

\section{Nonlinear finite element analysis}

In this section, the response of the stainless-steel girders subjected to patch loading is investigated through GMNIA using the software ANSYS [21]. An extensive parametric study was conducted to evaluate the influence of various geometrical parameters on the patch loading resistance. All components of the plate girder were modeled using the four-node shell element S181 [21] with six degrees of freedom at each node. To account for material nonlinear behavior, a multilinear true stressstrain curve was defined using Ramberg-Osgood expression Equation (1) with strain hardening.

$$
\epsilon=\frac{\sigma}{E}+0.002\left(\frac{\sigma}{\sigma_{0.2}}\right)^{n}
$$

Initial geometric imperfections were simulated using the first buckling mode of a plate girder subjected to patch loading obtained through eigenvalue analysis. A maximum geometrical web imperfection of $w_{0}=\min \left(h_{w}\right.$ $\left./ 100, t_{w}\right)$ was considered in the numerical models [2].

Simply supported boundary conditions were employed in the numerical model. In one end, displacements in $x$ and $y$ directions were restricted, and all nodes along the other support were free to move longitudinally ( $x$-direction). A concentrated load was applied on the nodes located over an equivalent length $s_{s}$ in the upper flange, in which the displacements in the $x$ and $z$ directions and all rotations were restricted, allowing only the vertical displacement in the $y$ direction.

The nonlinear response in the post-buckling region was captured using the Riks method [22]. The finite element model was validated using test results obtained by Unosson [14], see Table 1. Young modulus and Poisson ratio were taken as $E=200 \mathrm{GPa}$ and $v=0.3$.

Figure 2 shows a finite element mesh with 4352 elements selected after performing a convergence study. A good agreement was attained for the $F^{E x p} / F_{u}^{F E A}$ between experimental and numerical resistances with an average of 0.96 .

Table 1. Geometric and material properties of the stainless-steel girders tested by Unosson [14]

\begin{tabular}{|l|c|c|c|c|c|c|c|c|c|c|c|}
\hline \multirow{2}{*}{ Specimen } & $\boldsymbol{a}$ & $\boldsymbol{h}_{\boldsymbol{w}}$ & $\boldsymbol{t}_{\boldsymbol{w}}$ & $\boldsymbol{b}_{\boldsymbol{f}}$ & $\boldsymbol{t}_{\boldsymbol{f}}$ & $\boldsymbol{s}_{\boldsymbol{s}}$ & $\boldsymbol{\sigma}_{\mathbf{0 . 2 w}}$ & $\boldsymbol{\sigma}_{\mathbf{0 . 2 f}}$ & $\boldsymbol{F}^{\boldsymbol{E x p}}$ & $\boldsymbol{F}_{\boldsymbol{u}}^{\boldsymbol{F E A}}$ & \multirow{2}{*}{$\boldsymbol{F}^{\boldsymbol{E x p}}$} \\
\cline { 2 - 12 } & {$[\mathbf{m m}]$} & {$[\mathbf{m m}]$} & {$[\mathbf{m m}]$} & {$[\mathbf{m m}]$} & {$[\mathbf{m m}]$} & {$[\mathbf{m m}]$} & {$[\mathbf{M P a}]$} & {$[\mathbf{M P a}]$} & {$[\mathbf{k N}]$} & {$[\mathbf{k N}]$} & $\boldsymbol{F}_{\boldsymbol{u}}^{\boldsymbol{F E A}}$ \\
\hline Pli 4301:1 & 998 & 238 & 4.10 & 118.5 & 11.7 & 40.0 & 297 & 285 & 176.0 & 186.8 & 0.94 \\
\hline Pli 4301:2 & 996 & 238 & 4.10 & 119.9 & 11.9 & 80.0 & 297 & 285 & 196.0 & 208.0 & 0.94 \\
\hline Pli 4301:3 & 1397 & 316 & 4.10 & 121.0 & 11.9 & 40.0 & 297 & 285 & 168.0 & 183.4 & 0.91 \\
\hline Pli 4301:4 & 1623 & 438 & 4.10 & 121.2 & 11.9 & 40.0 & 297 & 285 & 169.0 & 179.3 & 0.94 \\
\hline Pli 4301:5 & 1682 & 401 & 8.80 & 120.4 & 12.0 & 40.0 & 245 & 285 & 478.0 & 446.2 & 1.07 \\
\hline
\end{tabular}

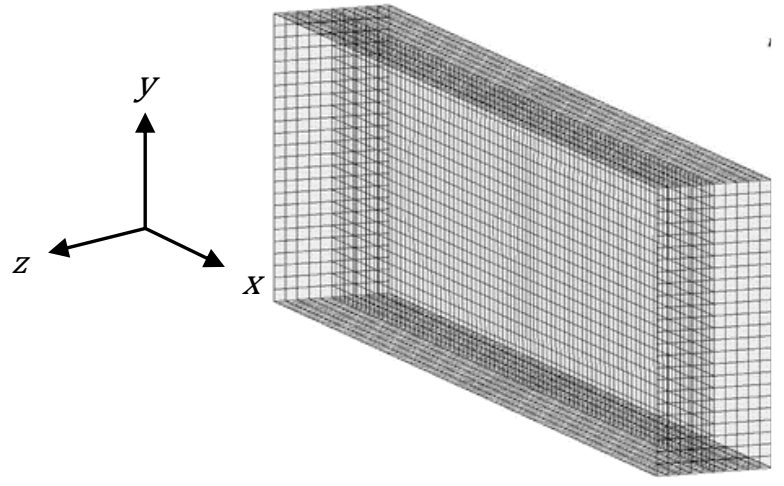

Figure 2. Finite element mesh. 


\section{Parametric analysis}

In the previous section the numerical model was validated. Using this model, a parametric analysis is performed using the following geometric parameters:

- $h_{w}=400,200 \mathrm{~mm}$

- $\quad a / h_{w}=1,1.25,1.50,1.75,2$

- $h_{w} / t_{w}=75,100,125,150,175,200$

- $s_{s} / h_{w}=0.10,0.15,0.20,0.25,0.30,0.35,0.40,0.50$

- $t_{f} / t_{w}=1,1.25,1.50,1.75,2,2.25,2.50,2.75,3$, $3.25,3.50,3.75,4$

Table 2 shows the remaining dimensions and material properties, that were kept constant through the analysis. It is noteworthy mentioning that the section class for all modeled girders satisfies the requirements for slender Class 4 cross-sections and the flanges meet $b_{f} / t_{f}<25$.

Table 2. Geometric and material properties of the girder

\begin{tabular}{|c|c|c|c|c|c|c|}
\hline $\begin{array}{c}\boldsymbol{b}_{\boldsymbol{f}} \\
{[\mathbf{m m}]}\end{array}$ & $\begin{array}{c}\boldsymbol{E} \\
{[\mathbf{G P a}]}\end{array}$ & $\boldsymbol{v}$ & $\begin{array}{c}\boldsymbol{\sigma}_{\mathbf{0 . 2}} \\
{[\mathbf{M P a}]}\end{array}$ & $\boldsymbol{n}$ & $\begin{array}{c}\boldsymbol{\sigma}_{\mathbf{1 . 0}} \\
{[\mathbf{M P a}]}\end{array}$ & $\begin{array}{c}\boldsymbol{\sigma}_{\boldsymbol{u}} \\
{[\mathbf{M P a}]}\end{array}$ \\
\hline 120 & 200 & 0.30 & 285 & 9 & 334 & 611 \\
\hline
\end{tabular}

The patch loading resistance for each combination of the parameters $\left(h_{w}, a / h_{w}, h_{w} / t_{w}, s_{s} / h_{w}\right.$, and $\left.t_{f} / t_{w}\right)$ was computed numerically, therefore a total of 5940 runs were performed. The computed resistances are employed in the comparative analysis of the resistance models in Section 5.

Figure 3 illustrates the von Mises stress distribution for various flange-to-web thickness ratios $t_{f} / t_{w}$. For all cases, the most stressed area is distributed in the upper region of the web panel, specifically in the region between the loaded flange and web panel.

The results also show that the most stressed is enlarged when $t_{f} / t_{w}$ is increased, and the resistance $F_{u}$ is enhanced $37.7 \%$, from 90.3 to $124.3 \mathrm{kN}$ when the thickness ratio $t_{f} / t_{w}$ goes from 1 to 4 . It is also interesting to observe that the maximum stress at failure in Figure 3 is 1.12 times higher than the yield stress reported in Table 2 (i.e. $\sigma_{0.2}=285 \mathrm{MPa}$ ). Usually, numerical models for carbon steel girders are elaborated considering a perfect elastoplastic material behavior, hence the maximum stress at failure is equal to the material yield strength. As stated in the introduction, stainless steel alloys exhibit a rounded stress-strain curve with significant strain hardening. Consequently, the level of stress at failure should be larger than its corresponding yield stress.

\section{Results}

\subsection{AISC 370 Specifications}

In the AISC 370 Specification [1], the patch loading resistance for transversally unstiffened stainless steel plate girders $F_{R d}$ is calculated with the same formulation used for carbon steel girders:

(a) When the concentrated force is applied at a distance from the member end greater than or equal to $d / 2$, the ultimate strength is calculated as

$$
F_{R d}=0.80 f_{y w} t_{w}^{2}\left[1+3\left(\frac{s_{s}}{d}\right)\left(\frac{t_{w}}{t_{f}}\right)^{1.5}\right] \sqrt{\frac{E f_{y w} t_{f}}{t_{w}}}
$$

(b) When a concentrated force is applied at a distance from the member end less than $d / 2$ :

For $s_{s} / d \leq 0.2$

$$
F_{R d}=0.40 f_{y w} t_{w}^{2}\left[1+3\left(\frac{s_{s}}{d}\right)\left(\frac{t_{w}}{t_{f}}\right)^{1.5}\right] \sqrt{\frac{E f_{y w} t_{f}}{t_{w}}}
$$

For $s_{s} / d>0.2$

$$
F_{R d}=0.40 f_{y w} t_{w}^{2}\left[1+\left(\frac{4 s_{s}}{d}-0.2\right)\left(\frac{t_{w}}{t_{f}}\right)^{1.5}\right] \sqrt{\frac{E f_{y w} t_{f}}{t_{w}}}
$$

In Eqs. (2) to (4), $d$ corresponds to the girder depth $h_{w}$.

\subsection{EC3:1-4}

In the EC3:1-4 [2], the procedure to calculate the patch loading resistance of stainless-steel plate girders without intermediate stiffeners $F_{R d}$ is the same developed for carbon steel girders in the EC3:1-5 [11]:

$$
F_{R d}=f_{y w} L_{e f f} t_{w} / \gamma_{M 1}
$$

in which $f_{y w}$ is the yield strength of the web, $\gamma_{M 1}$ is a partial safety factor, and $L_{e f f}$ is the effective length for resistance to transverse loads

$$
L_{e f f}=\chi_{F} l_{y}
$$

The reduction factor $\chi_{F}$ due to local buckling is

$$
\chi_{F}=\frac{0.5}{\bar{\lambda}_{F}} \leq 1.0
$$

and the effective load length $l_{y}$ is given by

$$
l_{y}=s_{s}+2 t_{f}\left(1+\sqrt{m_{1}+m_{2}}\right) \leq a
$$

where $m_{1}$ and $m_{2}$ are dimensionless parameters

$$
\begin{gathered}
m_{1}=f_{y f} b_{f} / f_{y w} t_{w} \\
m_{2}=0.02\left(h_{w} / t_{f}\right)^{2}
\end{gathered}
$$



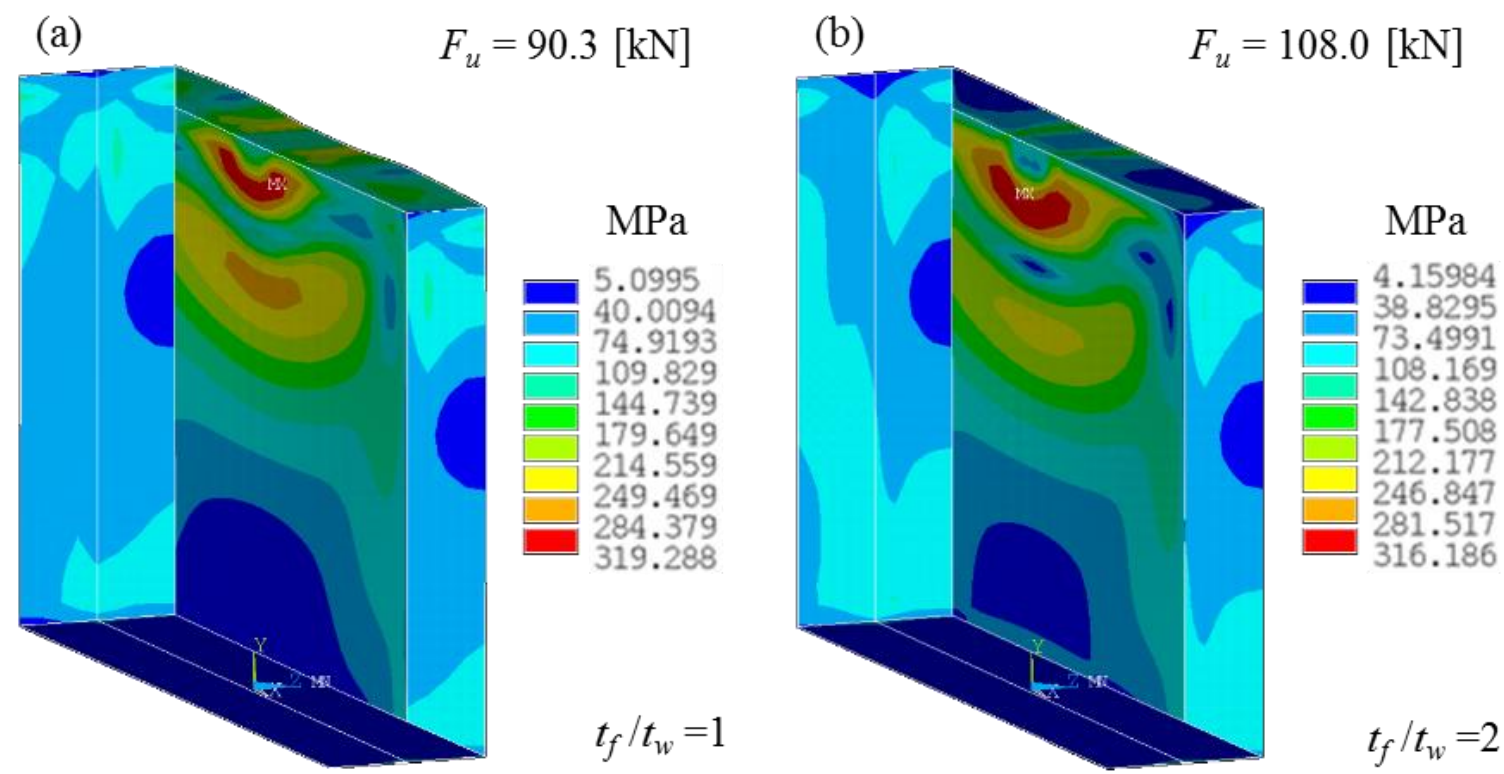

(c)

$$
F_{u}=116.6[\mathrm{kN}]
$$

(d)

$$
F_{u}=124.3[\mathrm{kN}]
$$
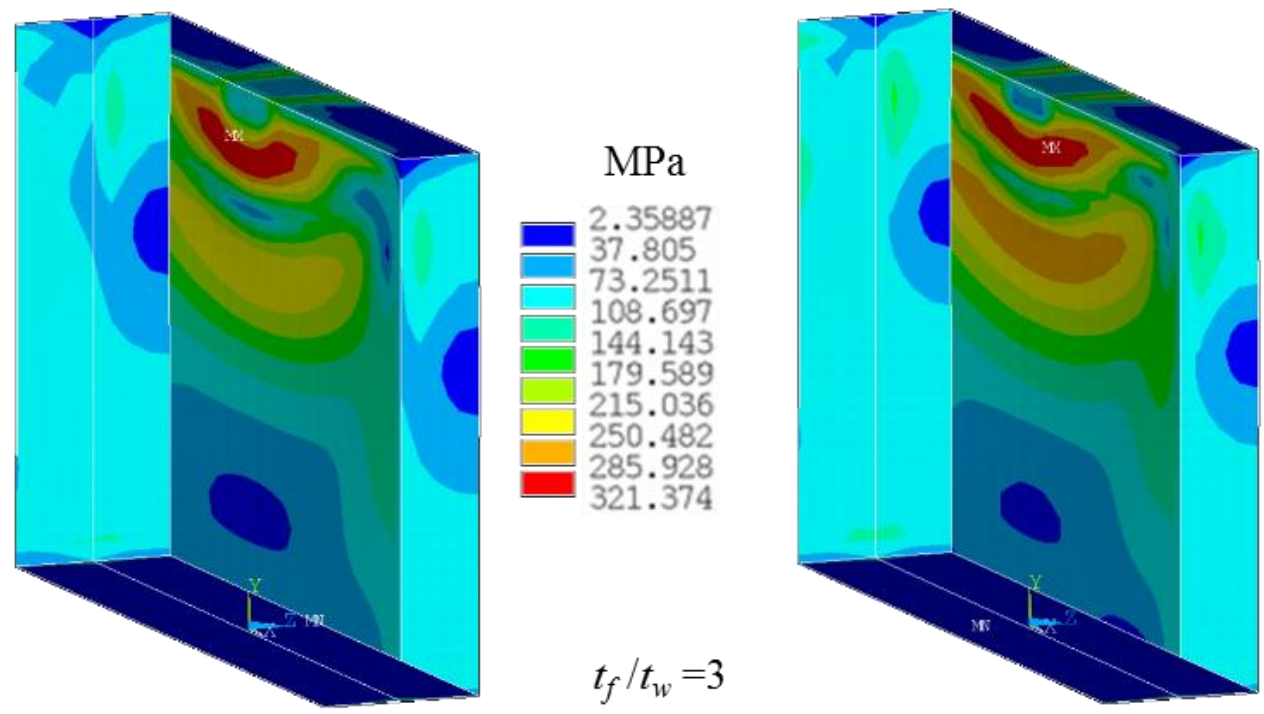

$\mathrm{MPa}$

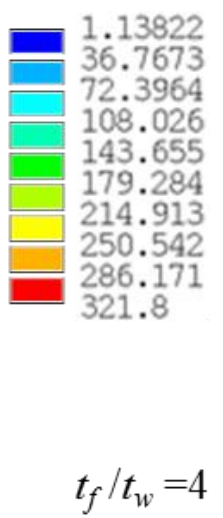

Figure 3. Von Mises stress distribution for various flange-to-web thickness ratio $t_{f} / t_{w}$.

$$
\left(h_{w}=400, a / h_{w}=1.50, h_{w} / t_{w}=200 ; s_{s} / h_{w}=0.2\right) \text {. }
$$

In Equation (8), $m_{2}$ should be taken as zero if $\bar{\lambda}_{F}<0.5$ The slenderness parameter $\bar{\lambda}_{F}$ is obtained from

$$
\bar{\lambda}_{F}=\sqrt{\frac{F_{y}}{F_{c r}}}
$$

$F_{y}$ is the yield resistance

$$
F_{y}=f_{y w} t_{w} l_{y}
$$

The buckling load $F_{c r}$ is

$$
\begin{gathered}
F_{c r}=0.9 k_{F} E t_{w}^{3} / h_{w} \\
k_{F}=6+2\left(\frac{h_{w}}{a}\right)^{2}
\end{gathered}
$$




\subsection{Calibration of the resistance function $\chi_{F}$}

Recently, a resistance function $\chi_{F}$ has been used for all verifications of structural compressed members within the EC3:1-5 [11].

where

$$
\chi_{\mathrm{F}}=\frac{1.0}{\phi+\sqrt{\phi^{2}-\bar{\lambda}_{\mathrm{F}}}} \leq 1
$$

$$
\phi=\frac{1}{2}\left[1+\alpha_{\mathrm{F} 0}\left(\bar{\lambda}_{\mathrm{F}}-\bar{\lambda}_{\mathrm{F} 0}\right)+\bar{\lambda}_{\mathrm{F}}\right]
$$

Employing a standard evaluation procedure provided in EN 1990 [24], Graciano et al. [16] and dos Santos and Gardner [17] calibrated, the imperfection factor $\alpha_{F 0}$ and the plateau length $\bar{\lambda}_{F 0}$ for a given level of safety $\gamma_{M 1}$. Table 3 shows the results for these calibrations.

Table 3. $\alpha_{F 0}, \bar{\lambda}_{F 0}$ and $\gamma_{M I}$ calibrated for stainless steel girders

\begin{tabular}{|l|c|c|c|}
\hline \multicolumn{1}{|c|}{ Proposal } & $\boldsymbol{\alpha}_{\boldsymbol{F} \mathbf{0}}$ & $\overline{\boldsymbol{\lambda}}_{\boldsymbol{F} \mathbf{0}}$ & $\boldsymbol{\gamma}_{\boldsymbol{M} \mathbf{1}}$ \\
\hline Graciano et al. [16] & 0.40 & 0.10 & 1.05 \\
\hline Dos Santos and Gardner [17] & 0.60 & 0.60 & 1.10 \\
\hline
\end{tabular}

It is worth pointing out that for the effective load length $l_{y}$-in Equation (8)- in the calibration conducted by Graciano et al. [16] the best results were attained with $m_{2} \neq 0$, and dos Santos and Gardner [17] only considered $m_{2}=0$.

\subsection{Machine learning approach}

Graciano et al. [25] based on a machine learning approach proposed a formulation for the patch loading resistance of austenitic slender plate girders

$$
F_{R d}=25.13 \times 10^{-3} f_{y w} t_{w}^{2} \xi_{g}
$$

with

$$
\xi_{g}=\left(\frac{t_{f}}{t_{w}}\right)^{0.415}\left(\frac{h_{w}}{\mathrm{a}}\right)^{0.211}\left(\frac{s_{s}}{h_{w}}\right)^{0.22}\left(\frac{b_{f}}{t_{f}}\right)^{0.224}
$$

\section{Comparative analysis of resistance models}

This section presents a comparative analysis of the resistance models presented. Figure 4 shows a comparison of the mean values for the ratio between the resistances obtained numerically $F_{u}$ and those obtained using various formulations $F_{R d}$. Comparing the mean values, the methodology proposed by Graciano et al. [25] using symbolic regression yields the lowest value $m=1.00$.

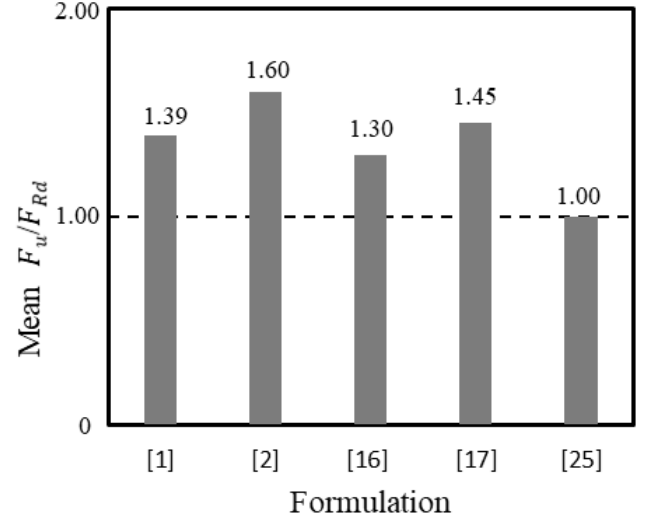

Figure 4. Comparison of mean values for the ratio F_u/F_Rd obtained using various formulations.

In addition, Table 4 shows the basic statistics for the ratio $F_{u} / F_{R d}$. Using AISC 370 Specifications [1] gives a mean $m=1.39$, with the largest scatter in the results $s=0.57$ and becoming unsafe in some cases with a minimum $\min =0.62$. Predicted resistances using the EC3:1-4 [2] are on the safe side with $m=1.39$ and $s=0.19$. It is worth noting that the design procedures in [1] and [2] correspond to carbon steel girders, and then extended to stainless steel girders without considering the difference in material behavior.

Table 4. Basic statistics for the ratios $F_{-} u / F \_R d$. obtained using the formulations in [16], [17] and [25]

\begin{tabular}{|c|c|c|c|c|c|}
\hline Model & $\min$ & $\max$ & $\boldsymbol{m}$ & $\boldsymbol{s}$ & $\boldsymbol{v}$ \\
\hline$[1]$ & 0.62 & 2.71 & 1.39 & 0.57 & 0.41 \\
\hline$[2]$ & 2.02 & 1.02 & 1.60 & 0.19 & 0.12 \\
\hline$[16]$ & 0.99 & 1.52 & 1.30 & 0.09 & 0.07 \\
\hline$[17]$ & 1.06 & 1.80 & 1.45 & 0.18 & 0.12 \\
\hline$[25]$ & 0.84 & 1.15 & 1.00 & 0.03 & 0.03 \\
\hline
\end{tabular}

An improvement in the predictions is achieved by calibrating the resistance function in Eq. (14). Graciano et al. [16] attained a mean $m=1.30$ with the lowest scatter $s=0.09$. Similarly, dos Santos and Gardner [17] attained a mean $m=1.45$ with the lowest scatter $s=0.18$. In both calibrations, the plastic yield resistance was obtained using the yield strength of the material. It may be suitable for carbon steel girders for which strain hardening is usually neglected. As seen in Figure 4, stainless steel girders reached a higher stress level at failure, i.e. 1.12 times greater than the material yield strength. 


\section{Conclusion}

This investigation presents a comparative analysis of resistances models for stainless steel plate girders subject to patch loading. A significant improvement in the predicted patch loading resistances is achieved by calibrating the resistance function for stainless steel girders. Further research is required to consider the strain hardening capacity of stainless-steel alloys in the formulation for the plastic yield resistance. From the results obtained herein, an appropriate level of stress, above the material yield strength, may be considered for this plastic yield resistance.

\section{Reference}

[1] Specification for Structural Stainless-Steel Buildings, American Institute of Steel Construction, AISC 370, 2020.

[2] Eurocode 3: Design of Steel Structures - Part 1-4: General Rules - Supplementary Rules for Stainless Steels, European Committee for Standardization, CEN ENV 1993-1-4, 2006.

[3] Eurocode 9: Design of Aluminium Structures - Part 1-1: General structural rules, European Committee for Standardization, CEN EN 1999-1-1:2007.

[4] Specification for structural steel buildings, American Institute of Steel Construction, EUA; ANSI/AISC 36016,2016

[5] Eurocode 3: Design of steel structures - Part 1-5: Plated structural elements, European Committee for Standardization, CEN ENV 1993-1-5, 2006.

[6] S. Afshan, L. Gardner, "The continuous strength method for structural stainless-steel design," Thin Walled Struct, vol. 68, pp. 42-49, 2013, doi: https://doi.org/10.1016/j.tws.2013.02.011.

[7] S. Ahmed, M. Ashraf, M. Anwar-Us-Saadat, "The continuous strength method for slender stainless-steel cross-sections," Thin-Walled Struct, vol. 107, pp. 362376, 2016, doi: https://doi.org/10.1016/j.tws.2016.06.023.

[8] O. Zhao, S. Afshan, L. Gardner, "Structural response and continuous strength method design of slender stainless-steel cross-sections," Eng Struct, vol. 140, pp. 14-25, 2017, doi: https://doi.org/10.1016/j.engstruct.2017.02.044.
[9] G. D. Matteis, L. A. Moen, M. Langseth, R. Landolfo, O. S. Hopperstad, F. M. Mazzolani, "Cross-sectional classification for aluminum beams - parametric study," $J$ Struct Eng ASCE, vol. 127, no. 3, pp. 271-279, 2001, doi: https://doi.org/10.1061/(ASCE)0733-

9445(2001)127:3(271).

[10] M. N. Su, B. Young, L. Gardner, "The continuous strength method for the design of aluminium alloy structural elements," Eng Struct, vol. 122, pp. 338-348, 2016, doi: https://doi.org/10.1016/j.engstruct.2016.04.040.

[11] M. N. Su, B. Young, L. Gardner, "Classification of aluminium alloy cross-sections," Eng Struct, vol. 141, pp. 29-40, 2017, doi: https://doi.org/10.1016/j.engstruct.2017.03.007.

[12] F. M. Mazzolani, Aluminium Alloy Structures, 2nd Ed., London, UK: Chapman \& Hall, 1995.

[13] O. Lagerqvist, B. Johansson, "Resistance of Igirders to concentrated loads," J Constr Steel Res, vol. 39, no. 2, pp. 87-119, 1996, doi: https://doi.org/10.1016/S0143-974X(96)00023-5.

[14] E. Unosson, "Patch loading of stainless steel girders: Experiments and finite analyses," licentiate thesis, Luleå University of Technology, 2003.

[15] G. B. dos Santos, L. Gardner, M. Kucukler, "Experimental and numerical study of stainless steel Isections under concentrated internal one-flange and internal two-flange loading," Eng Struct, vol. 175, pp. 355-370, 2018, doi: https://doi.org/10.1016/j.engstruct.2018.08.015.

[16] C. Graciano, N. Loaiza, E. Casanova, "Resistance of slender austenitic stainless steel I-girders subjected to patch loading," Structures, vol. 20, pp. 924-934, 2019, doi: https://doi.org/10.1016/j.istruc.2019.07.008.

[17] G. B. dos Santos, L. Gardner, "Design recommendations for stainless steel I-sections under concentrated transverse loading," Eng Struct, vol. 204, 109810, 2020, doi: https://doi.org/10.1016/j.engstruct.2019.109810.

[18] A. Ayestarán, C. Graciano, O. A. González-Estrada, "Resistencia de vigas esbeltas de acero inoxidable bajo cargas concentradas mediante elementos finitos," Rev UIS Ing, vol. 16, no. 2, pp. 61-70, 2017, doi: https://doi.org/10.18273/revuin.v16n2-2017006. 
[19] Eurocode 3: Design of Steel Structures - Part 1-6: Strength and Stability of Shell Structures, European Committee for Standardization, EN 1993-1-6, 2007.

[20] Eurocode 3: Design of Steel Structures - Part 1-1: General Rules and Rules for Buildings, European Committee for Standardization, EN 1993-1-1, 2005.

[21] Elements Reference, ANSYS Release 19R2, 2019.

[22] E. Riks, "An incremental approach to the solution of snapping and buckling problems," Int J Solids Struct vol. 15, no. 7, pp. 529-551, 1979, doi: https://doi.org/10.1016/0020-7683(79)90081-7.

[23] C. Müller, "Zum Nachweis ebener Tragwerke aus Stahl gegen seitliches Ausweichen," doctoral thesis, RWTH Aachen, Lehrstuhl für Stahlbau, Shaker Verlag, no. $47,2003$.

[24] Eurocode - Basis of structural design, EN BS 1990: 2002.

[25] C. Graciano, A. E. Kurtoglu, E. Casanova, "Machine learning approach for predicting the patch load resistance of austenitic steel girders," Structures, vol. 30, pp. 198205, 2021, doi: https://doi.org/10.1016/j.istruc.2021.01.012. 